\title{
Front Matter: Volume 8529
}

, "Front Matter: Volume 8529," Proc. SPIE 8529, Remote Sensing and Modeling of the Atmosphere, Oceans, and Interactions IV, 852901 (8 November 2012); doi: 10.1117/12.2016735

SPIE. Event: SPIE Asia-Pacific Remote Sensing, 2012, Kyoto, Japan 


\title{
Remote Sensing and Modeling of the Atmosphere, Oceans, and Interactions IV
}

\author{
Michio Kawamiya \\ Tiruvalam N. Krishnamurti \\ Shamil Maksyutov \\ Editors
}

31 October - 1 November 2012
Kyoto, Japan

Sponsored by

SPIE

Cosponsored by

JAXA-Japan Aerospace Exploration Agency (Japan) • NASA-National Aeronautics and Space Administration (United States) • National Institute of Information and Communications Technology (Japan) • Commemorative Organization for the Japan World Exposition (Japan)

ISRO_Indian Space Research Organization (India) • State Key Laboratory of Remote Sensing Science (China)

Cooperating Organizations

ISPRS-International Society for Photogrammetry and Remote Sensing

Supported by

Japan Society of Atmospheric Environment • Japan Society of Photogrammetry and Remote Sensing Laser Radar Society of Japan • Meteorological Society of Japan • Optical Society of Japan

Society of Environmental Science, Japan - Society of Geomagnetism and Earth, Planetary and Space Sciences • The Astronomical Society of Japan • The Geodetic Society of Japan • The Institute of Electrical Engineers of Japan • The Institute of Electronics, Information and Communication Engineers The Japan Society of Applied Physics • The Laser Society of Japan • The Remote Sensing Society of Japan • The Society of Instrument and Control Engineers • The Spectroscopical Society of Japan

Published by

SPIE

Volume 8529 
The papers included in this volume were part of the technical conference cited on the cover and title page. Papers were selected and subject to review by the editors and conference program committee. Some conference presentations may not be available for publication. The papers published in these proceedings reflect the work and thoughts of the authors and are published herein as submitted. The publisher is not responsible for the validity of the information or for any outcomes resulting from reliance thereon.

Please use the following format to cite material from this book:

Author(s), "Title of Paper," in Remote Sensing and Modeling of the Atmosphere, Oceans, and Interactions $I V$, edited by Michio Kawamiya, Tiruvalam N. Krishnamurti, Shamil Maksyutov, Proceedings of SPIE Vol. 8529 (SPIE, Bellingham, WA, 2012) Article CID Number.

ISSN: 0277-786X

ISBN: 9780819492685

Published by

SPIE

P.O. Box 10, Bellingham, Washington 98227-0010 USA

Telephone +1 3606763290 (Pacific Time) · Fax +1 3606471445

SPIE.org

Copyright (C) 2012, Society of Photo-Optical Instrumentation Engineers.

Copying of material in this book for internal or personal use, or for the internal or personal use of specific clients, beyond the fair use provisions granted by the U.S. Copyright Law is authorized by SPIE subject to payment of copying fees. The Transactional Reporting Service base fee for this volume is $\$ 18.00$ per article (or portion thereof), which should be paid directly to the Copyright Clearance Center (CCC), 222 Rosewood Drive, Danvers, MA 01923. Payment may also be made electronically through CCC Online at copyright.com. Other copying for republication, resale, advertising or promotion, or any form of systematic or multiple reproduction of any material in this book is prohibited except with permission in writing from the publisher. The CCC fee code is 0277-786X/12/\$18.00.

Printed in the United States of America.

Publication of record for individual papers is online in the SPIE Digital Library.

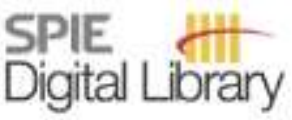

SPIEDigitalLibrary.org

Paper Numbering: Proceedings of SPIE follow an e-First publication model, with papers published first online and then in print and on CD-ROM. Papers are published as they are submitted and meet publication criteria. A unique, consistent, permanent citation identifier (CID) number is assigned to each article at the time of the first publication. Utilization of CIDs allows articles to be fully citable as soon as they are published online, and connects the same identifier to all online, print, and electronic versions of the publication. SPIE uses a six-digit CID article numbering system in which:

- The first four digits correspond to the SPIE volume number.

- The last two digits indicate publication order within the volume using a Base 36 numbering

system employing both numerals and letters. These two-number sets start with 00, 01, 02, 03, 04,

$05,06,07,08,09,0 A, 0 B \ldots$. 0Z, followed by 10-1Z, 20-2Z, etc.

The CID Number appears on each page of the manuscript. The complete citation is used on the first page, and an abbreviated version on subsequent pages. Numbers in the index correspond to the last two digits of the six-digit CID Number. 


\title{
Contents
}

\author{
$\checkmark \quad$ Conference Committee \\ vii The benefit of space derived geo-spatial information for sustainable development \\ (Keynote Speech) \\ Y. Horikawa, Japan Aerospace Exploration Agency (Japan) \\ xiii JAXA earth observation program update (Plenary Paper) [8523-507] \\ M. Homma, Japan Aerospace Exploration Agency (Japan)
}

REMOTE SENSING AND MODELING I

852902 Precipitation characteristics around Bangladesh revealed by TRMM data [8529-2]

K. Nakamura, F. A. Furuzawa, M. Nishikawa, F. Shiratsu, D. Shrestha, Nagoya Univ. (Japan)

852904 Is the simulated increasing trend of dry static stability true or not? [8529-4]

M. Sugi, Japan Agency for Marine-Earth Science and Technology (Japan)

\section{REMOTE SENSING AND MODELING II}

852907 Satellite-based 3D structure of cloud and aerosols over the Indian Monsoon region: implications for aerosol-cloud interaction [8529-7]

S. Dey, K. Sengupta, G. Basil, S. Das, N. Nidhi, S. K. Dash, A. Sarkar, P. Srivastava, A. Singh,

P. Agarwal, Indian Institute of Technology Delhi (India)

8529 OA Future Doppler lidar wind measurement from space in Japan [8529-10]

S. Ishii, National Institute of Information and Communications Technology (Japan);

T. Iwasaki, Tohoku Univ. (Japan); M. Sato, The Univ. of Tokyo (Japan); R. Oki, Japan

Aerospace Exploration Agency (Japan); K. Okamoto, T. Ishibashi, Meteorological Research Institute (Japan); P. Baron, National Institute of Information and Communications Technology (Japan); T. Nishizawa, National Institute for Environmental Studies (Japan)

REMOTE SENSING AND MODELING III

8529 OB Observing system simulation experiments at Joint Center for Satellite Data Assimilation [8529-11]

M. Masutani, National Oceanic and Atmospheric Administration (United States) and Joint Ctr. for Satellite Data Assimilation (United States) and Wyle Information Systems Inc. (United States); L. P. Riishojgaard, Joint Ctr. for Satellite Data Assimilation (United States) and Univ. of Maryland (United States); J. S. Woollen, National Oceanic and Atmospheric Administration (United States) and I.M. Systems Group (United States); S. Casey, Joint Ctr. for Satellite Data Assimilation (United States) and Univ. of Maryland (United States) 
8529 OD Integrated instrument simulator suites for Earth science [8529-13]

S. Tanelli, Jet Propulsion Lab. (United States); W.-K. Tao, T. Matsui, NASA Goddard Space Flight Ctr. (United States); C. Hostetler, J. Hair, C. Butler, NASA Langley Research Ctr. (United States); K.-S. Kuo, Caelum Research Corp. (United States); N. Niamsuwan, M. P. Johnson, J. C. Jacob, Jet Propulsion Lab. (United States); L. Tsang, Univ. of Washington (United States); K. Shams, S. Jaruwatanadilok, S. Oveisgharan, M. Simard, F. J. Turk, Jet Propulsion Lab. (United States)

8529 OG Estimation of regional surface $\mathrm{CO}_{2}$ fluxes with GOSAT observations using two inverse modeling approaches [8529-16]

S. Maksyutov, H. Takagi, National Institute for Environmental Studies (Japan); D. A. Belikov, National Institute for Environmental Studies (Japan) and National Institute of Polar Research (Japan); T. Saeki, National Institute for Environmental Studies (Japan); R. Zhuravlev, A. Ganshin, A. Lukyanov, Central Aerological Observatory (Russian Federation); Y. Yoshida, S. Oshchepkov, A. Bril, National Institute for Environmental Studies (Japan); M. Saito, Lab. des Sciences du Climat et de I'Environnement (France); T. Oda, Colorado State Univ. (United States) and National Oceanic and Atmospheric Administration (United States); V. K. Valsala, Indian Institute of Tropical Meteorology (India); R. Saito, Japan Agency for Marine-Earth Science and Technology (Japan); R. J. Andres, Oak Ridge National Lab. (United States); T. Conway, P. Tans, National Oceanic and Atmospheric Administration (United States); T. Yokota, National Institute for Environmental Studies (Japan)

POSTER SESSION

8529 Ol Evaluating the spatial and temporal solar energy potential in South Korea [8529-19]

S.-Y. Oh, J.-K. Park, J.-H. Park, Chungbuk National Univ. (Korea, Republic of)

8529 0J Spatio-temporal variability of drought over northern China and its relationships with IndianPacific sea surface temperatures [8529-21]

Q. Dong, C. Xue, Y. Ren, Ctr. for Earth Observation and Digital Earth (China)

8529 OK Semi-diurnal variation of surface rainfall studied from global cloud-system resolving model and satellite observations [8529-23]

T. Inove, The Univ. of Tokyo (Japan); K. Rajendran, C-MMACS (India); M. Satoh, The Univ. of Tokyo (Japan) and Japan Agency for Marine-Earth Science and Technology (Japan);

H. Miura, The Univ. of Tokyo (Japan); J. Schmetz, EUMETSAT (Germany)

Author Index 


\title{
Conference Committee
}

\author{
Symposium Chairs \\ Upendra Singh, NASA Langley Research Center \\ (United States) \\ Toshio Iguchi, National Institute of Information and \\ Communications Technology (Japan) \\ Symposium Cochair
}

A. S. Kiran Kumar, Space Applications Center (India)

\section{Conference Chairs}

Michio Kawamiya, Japan Agency for Marine-Earth Science and Technology (Japan)

Tiruvalam N. Krishnamurti, The Florida State University (United States)

Shamil Maksyutov, National Institute for Environmental Studies (Japan)

\section{Session Chairs}

1 Remote Sensing and Modeling I

Tiruvalam N. Krishnamurti, The Florida State University (United States)

2 Remote Sensing and Modeling II

Guosheng Liu, The Florida State University (United States)

3 Remote Sensing and Modeling III

Kenji Nakamura, Nagoya University (Japan)

4 Remote Sensing and Modeling IV

Shu-Hua Chen, University of California, Davis (United States) 
Proc. of SPIE Vol. $8529852901-6$

Downloaded From: https://www.spiedigitallibrary.org/conference-proceedings-of-spie on 26 Apr 2023 Terms of Use: https://www.spiedigitallibrary.org/terms-of-use 


\title{
The benefit of Space derived Geo-spatial information for Sustainable Development
}

\author{
Yasushi Horikawa \\ Japan Aerospace Exploration Agency (Japan)
}

\begin{abstract}
As Chairman of the UN COPUOS I deal with many problems related to collaboration amongst UN Member States who are attempting to reach consensus on the use of space data technology and applications for the purpose of solving regional or global problems which affect all of humanity and to help sustainable development at a global level.
\end{abstract}

At this time, space science and exploration, Earth observations, climate change research, the sharing of environmental data, disaster mitigation and relief, space surveillance for near earth objects for debris monitoring and awareness are the most demanding fields for international collaboration. I consider the UN COPUOS to be the highest international platform for political, scientific, technical and legal debates connected with space, a platform for negotiations, elaboration and promotion of important international treaties, agreements, UN resolutions and guide-lines for all member states.

The UN COPUOS is at the same time both a reflection and an integration of most global and regional forums of cooperation in the space field. In an era where space is becoming increasingly crowded with new players the need to share a commitment to act responsibly to help prevent mishaps, misperceptions and mistrust has become a must.

In 2011, the United Nations celebrated the fiftieth anniversary of the Committee on the Peaceful Uses of Outer Space and recalled its outstanding achievements in ensuring that outer space was used for peaceful purposes. The declaration of the $50^{\text {th }}$ anniversary expressed deep concerns about the fragility of the space environment, that is, the continuing threat of the impact of space debris. Long term sustainability of space activities is now one of the most challenging topics under discussion at the UN COPUOS and a topic that needs real global cooperation and understanding.

As you know, the primary objective of COPUOS is to maximize the benefits of space science, technology, their applications and to increase coherence, synergy, and international cooperation in space activities at various levels including national, regional, and global instrumental support efforts with special consideration for the needs of developing countries. Aiding this effort, the United States launched the first civilian Earth observation satellite, Landsat-1, on July 23, 1972, an achievement whose $40^{\text {th }}$ year anniversary was celebrated this June at UNCOPUOS. 
As you know, Earth observation from space has become a significant tool to benefit human life by helping illuminate dangers to our societies like global climate change due to global warming and the consequent problems of food security and global health, all of which are interlinked with disasters and poverty.

As such, we need a holistic approach to these problems and concerns in order to make sound long-term decisions for humanity's future. The 1992 Earth summit held in Rio de Janeiro neither recognized nor mentioned the use of such space tools to meet human needs on Earth. In the first draft of the Rio+20 Conference document the word "space" was not mentioned once even though today over $75 \%$ of the world is space-knowledgeable and consumes a large amount of space products and services daily. A timely and adapted integration of remote sensing, satellite telecommunication, and global navigation satellite systems to multi-source geospatial datasets will provide some key factors needed to resolve these difficulties.

With increasing awareness of, and concern for, the environmental impacts on Earth caused by global warming and related climate changes we should recognize the critical importance of monitoring these changes and devise climate change mitigation and adaptation measures. Joint development of interoperable systems to address such issues is an important area for international cooperation. The above circumstances notwithstanding, the collection, analysis and use of available information, including the space-acquired ones, to properly manage our life-support systems has been confirmed in many parts of the world as a necessary starting point on the path towards sustainable development and must be rigorously pursued.

Although the issues relating to Earth observation satellite systems and their information accessibility and data policy are being discussed at the meetings of the Group on Earth Observations (GEO) and the Committee on Earth Observation Satellites (CEOS), due to the global nature of its work COPUOS should also address these data utilization issues and further promote the relevance of research in data analysis and utilization in order to strengthen international cooperation among its member States.

Disasters continuously affect our societies in all parts of the World and demonstrate repeatedly how vulnerable we are against the forces of nature and how important it is to strengthen our ability to mitigate the devastating effects of natural disasters.

Loss of life and property could be diminished if better information were available through improved risk assessment, early warning, and monitoring of disasters. In this regard, the integrated and coordinated use of space technologies and their applications can play a crucial role in supporting disaster management by providing accurate and timely information and communication support. 
After the Earthquake on 11 March 2011, JAXA, the Japanese space agency has been observing and analyzing of the disaster area with the Advanced Land Observing Satellite "Daichi" and other satellites of foreign space agencies. Japan once again thanks you for the kind support and help which came generously from all over the world. We have come to realize the importance of using satellite data for natural disaster preparation and response and we would like to share and reconfirm the importance of constant, regular images taken when disasters occur to compare the affected areas for crisis management and response.

The work currently being carried out by the Scientific and Technical Subcommittee through its Working Group on the Long-term Sustainability of Outer Space Activities is critically important. Its goal is to ensure the safe and sustainable use of outer space over many years by future generations.

To implement a set of practical and prudent measures for enhancing the long-term sustainability of space activities, the Working Group was established to address sustainable space utilization and the support of sustainable development on Earth, space debris, space weather, space operations, tools to support collaborative space situational awareness, regulatory regimes, and guidance for actors in the space arena. This is a remarkable undertaking with the objective to identify and examine a wide range of issues and concerns for the long term sustainability of space activities and to prepare a consolidated set of practices and operating procedures and guidelines.

The space environment is quite different from conditions on the ground and air because the position of a space vehicle cannot be easily changed since its movement or orbital behaviour is strictly constrained to the orbit onto which it has been launched. Given how congested the space environment is with satellites, the condition is being exacerbated further by a large amount of space debris. Space utilization for nations involved could become unnecessarily constrained unless the operations of all space vehicles and other space objects are well managed.

The role of international organizations and other entities in the space field continues to be of major importance to our common goal of promoting space activities at the national, regional, interregional and global level. I would like to underline the particular role of regional mechanisms in providing platforms for enhanced coordination and cooperation between space faring nations and emerging space nations and in establishing partnerships between users and providers of space-based services. In this regard I am pleased to note the activities, programs, projects and strategies being performed and developed through the African Leadership Conference on Space Science and Technology for Sustainable Development (ALC); the Asia-Pacific Regional Space Agency Forum (APRSAF); the Asia-Pacific Space Cooperation Organization (APSCO); and the Space Conference of the Americas. 
There is a need to strengthen international collaboration and support for data sharing and access to geospatial information which is expected to be useful in addressing the climate change associated with global warming, carbon cycles, water cycles, as well as human health, food security relating to agriculture and fisheries, and natural disasters.

More specifically, actions undertaken by the regional centers for space science and technology education affiliated with the United Nations could further advance the promotion of data utilization and relevant scientific research. The regional centers have firmly established infrastructures for advanced training in the field of space science and technology, and their long-standing education programmes have been highly successful. Likewise, the network of UN-SPIDER Regional Support Offices around the world caters to the regional coordination of efforts in the area of disaster risk reduction.

Today, various kinds of applications such as those for scientific observation missions, Earth resources observation, as well as educational and capacity building activities are being planned and carried out by an increasing number of governmental and non-governmental entities.

The operation of satellites, for example, gives rise to matters that could be further explored and discussed such as responsibility and liability under the legal regime on outer space. The application of the concept of the launching state in national regulatory frameworks, registration and notification measures, and the continuing development of national regulatory frameworks, as well as guidance to space actors should be understood. Even satellites launched for educational or training purposes should follow international regimes for registration, frequency coordination and liability for damages. In this regard, satellite should be designed for a certain level of reliability. To comply with this, it should be recommended that all satellite programs be reviewed by experts who have substantial experiences in this field.

Space technology provides a wide range of essential tools for making informed decisions in support of development at local, national, regional and global levels in both public and private domains. Information generated from space-derived geospatial data is indispensable in areas such as agriculture, climate change, forestry, public health, disasters, food security, land management, and urban growth. A continuous monitoring and observation system that feeds into decision support systems and ensures an informed decision-making process is crucial. There is a need to ensure a clear view of the planet's status at near real-time and at any given moment. The practical benefits of space technology applications today touch virtually every human endeavor extending across communication, navigation, meteorology, education, health, agriculture, resource management, 
environmental protection and disaster management. To adapt to emerging and future challenges to the global community, the United Nations system, in close coordination with its Member States, needs to find effective solutions to current and emerging global problems.

The United Nations System Task Team on the Post-2015 UN Development Agenda has presented its report to the Secretary-General of the United Nations entitled "Realizing the Future We Want for All". This is a comprehensive assessment of the overall involvement of the UN system and the report will be part of the process leading up to 2015. There are many areas covered in the report where spacebased technologies and data are of crucial importance. In direct relation to space tools, I would like to bring to your attention to the scientific understanding of space environments, as well the importance of improved access to geographical information and geospatial data for more accurate environmental and social impact assessments and more informed decision-making at all levels.

The formulation and implementation of sustainable development policies can succeed only with accurate information concerning the Earth system which today's highly accurate satellites can provide. To be able to gauge and manage societal impacts on our planet, the global community will continue to require consistent and accurate information that can be used to measure such impacts. As an enabler of informed decision-making at all levels of society, space acquired data can produce a shared vision and understanding which in turn can produce joint action. The millennium development goals (MDG) belong to this category of actions which, if attained, can foster global yearning for sustainable development. 
Proc. of SPIE Vol. $8529852901-12$

Downloaded From: https://www.spiedigitallibrary.org/conference-proceedings-of-spie on 26 Apr 2023 Terms of Use: https://www.spiedigitallibrary.org/terms-of-use 